\title{
The action of secretin and pancreozymin on small-intestinal alkaline phosphatase
}

\author{
T. W. WARNES, P. HINE, AND G. KAY \\ From the Department of Gastroenterology, Manchester Royal Infirmary
}

SUMMARY The hormones secretin and cholecystokinin-pancreozymin (CCK) have been shown to release brush-border alkaline phosphatase into the small-intestinal lumen in the human subject.

In contrast to the disaccharidases, large amounts of alkaline phosphatase are present in human duodenal juice. The range has been established in normal subjects. Following the intravenous administration of both secretin and CCK-pancreozymin there is a large rise in the output of alkaline phosphatase in human duodenal juice. These rises are also present in patients with complete obstruction of the common bile and pancreatic ducts, and since the pancreatic juice of man contains negligible amounts of alkaline phosphatase, it is clear that both hormones must cause small-intestinal alkaline phosphatase to be released into duodenal juice. The isoenzyme characteristics of bile, smallintestinal, and pancreatic alkaline phosphatase have been established, and isoenzyme studies used to confirm this new action of secretin and CCK-pancreozymin.

In 1969 a new action of the hormones secretin and CCK-pancreozymin on small-intestinal alkaline phosphatase was reported (Warnes, Hine, and Kay, 1969), and the following year an expanded version of the same work was presented at the 4th World Congress of Gastroenterology (Warnes, Hine, and Kay, 1970). Full details of these findings, previously published in abstract form, are now presented.

It has been known for many years that bile (Greene, Shattuck, and Kaplowitz, 1934) and intestinal mucosa (Gomori, 1941) contain considerable amounts of alkaline phosphatase, whilst more recently the enzyme has been demonstrated in both the normal human pancreas and in pancreatic tumours (Warnes, Timperley, Hine, and Kay, 1972). It is also known that in some species alkaline phosphatase is secreted into pancreatic juice (Nothmann, 1944). Infusion of fatty acids releases alkaline phosphatase from human duodenal mucosa: this effect may be due to an alteration of membrane permeability, since, although small amounts of sucrase are liberated, no dipeptidase is released, which makes lysis of small-intestinal epithelium unlikely (Linscheer, Pihl, Wehr, and Fishman, 1970). Perfusion of the human small intestine with glucose also releases small-intestinal alkaline phosphatase, and glucose infused into a mid-jejunal segment pro-

Received for publication 8 October 1973, duces a rise in the alkaline phosphatase content of an isolated proximal jejunal segment perfused with control solution. It has therefore been suggested that the intestinal release of alkaline phosphatase might be mediated by a humoral factor (Linscheer, Blum, Inglis, and Fishman, 1967). Since secretin and pancreozymin are released by both fats and carbohydrates introduced into the duodenum (Wang and Grossman, 1951), it seemed possible that one or both of these two hormones might be responsible for the release of small-intestinal alkaline phosphatase into duodenal juice.

There appear to be few previous studies on alkaline phosphatase in human duodenal juice either in health or disease, though the measurement of its content in duodenal juice during the secretinpancreozymin test of pancreatic and biliary function (Burton, Evans, Harper, Howat, Oleesky, Scott, and Varley, 1960a; Burton, Harper, Howat, Scott, and Varley, 1960b) has been used for many years as a rough index of total recovery of duodenal juice (H. T. Howat, personal communication). In duodenal juice the alkaline phosphatase may originate from bile, intestinal mucosa, or pancreatic juice. To elucidate this problem we have studied patients with complete biliary obstruction and patients with complete obstruction of the pancreatic duct as well as normal subjects.

The isoenzymes of alkaline phosphatase in serum 
can be differentiated by means of heat inactivation (Posen, Neale, and Clubb, 1965) and urea inhibition (Bahr and Wilkinson, 1967), as well as by electrophoresis on a variety of media (Newton, 1967; Kaplan and Rogers, 1969), whilst intestinal alkaline phosphatase can be evaluated both electrophoretically and by L-phenylalanine inhibition tests (Fishman, Green, and Inglis, 1963). We have adapted these techniques to characterize the alkaline phosphatases of bile, pancreas, and intestinal mucosa.

\section{Materials and Methods}

Secretin $^{1}$ (in a submaximal dose of 1.7 Crick-HarperRaper units per kilogram body weight) and pancreozymin $^{1}$ ( $2.0 \mathrm{C}-\mathrm{H}-\mathrm{R}$ units/kg body weight) were administered intravenously as discrete injections during tests of pancreatic and biliary function, as described by Burton et al (1960a and b). The duodenal contents were aspirated quantitatively, uncontaminated by gastric acid, by means of a doublelumen Dreiling tube for at least one 10-minute control period before the injection of secretin, after which three 10-minute collections were made. Pancreozymin was then given intravenously and juice aspirated for three further 10-minute periods. The concentrations of pancreatic enzymes, bilirubin, and alkaline phosphatase were measured and the 10-minute outputs were calculated from these concentrations and the volumes of the samples.

Pancreatic juice was obtained postoperatively from cannulae placed in the main pancreatic duct in patients who had recently undergone distal pancreatectomy for cancer of the pancreas or distal pancreatitis. Bile was obtained postoperatively by $\mathrm{T}$-tube drainage of the common bile duct.

Amylase was measured by Lagerlöf's adaptation of the method of Nørby (Lagerlöf, 1942), trypsin by the method of Gowenlock (1953), and lipase by the method of Cherry and Crandall (1932), whilst the icteric index of Meulengracht (Burton et al, 1960b) was used as a measure of the concentration of bile in the duodenal contents. The disaccharidases-maltase, sucrase, and lactase - were measured by the method of Dahlqvist (1964). Alkaline phosphatase was measured by a modification (Kind and King, 1954) of the King-Armstrong method. Extraction of the enzyme from human small intestine and pancreas was performed by a modification of the butanol extraction method of Morton (1954) on specimens obtained at the time of operation.

The bile, pancreatic, and small-intestinal isoenzymes of alkaline phosphatase were characterized by heat inactivation at $56^{\circ} \mathrm{C}$ for 15 minutes, by in'Boots Pure Drug Co. Ltd, Nottingham. hibition with $1 \mathrm{M}$ urea, and by inhibition with 0.005 M L-phenylalanine (Warnes et al, 1972). Electrophoretic separation of the three isoenzymes was performed by acrylamide gel disc electrophoresis and the enzyme bands were located by staining with beta-naphthyl phosphate and Fast Blue BB salt (Warnes et al, 1972). Some samples were treated with neuraminidase before electrophoresis (type VI Clostridium perfringens, from Sigma Chemical Co.) using a modification of the method of Robinson and Pierce (1964).

\section{Results}

Studies on 16 normal subjects showed that a rise in the output of alkaline phosphatase followed the intravenous injection of both secretin and pancreozymin (fig 1); in each case this rise was statistically significant. These rises in output of alkaline phosphatase were accompanied by a flow of bile and pancreatic enzymes into duodenal juice (fig 2). The rise in output following pancreozymin closely paralleled the rises in the outputs of bilirubin and pancreatic enzymes represented by amylase. Following secretin the rise in output of alkaline phosphatase closely paralleled the rise in output of pancreatic enzymes, but not so closely that of bilirubin. Negligible amounts of sucrase and lactase were found in human duodenal juice, and there was no rise in

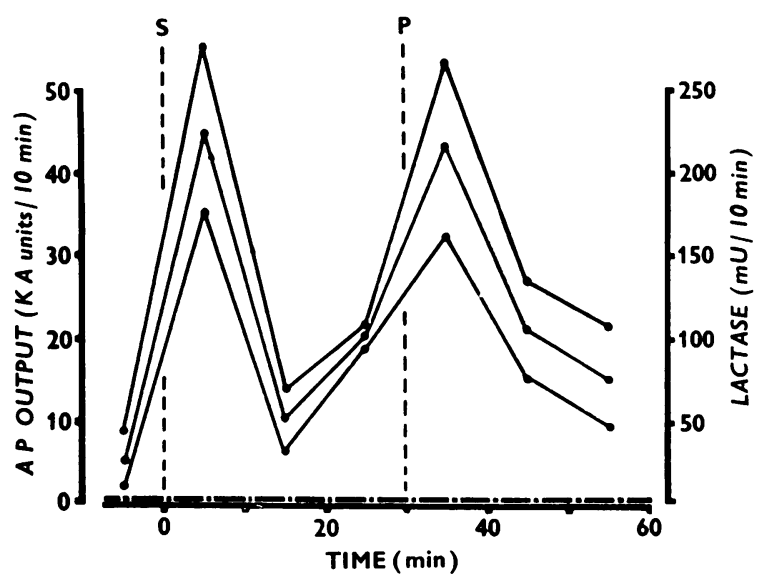

Fig 1 Output of alkaline phosphatase in 16 normals following $1.7 \mathrm{C}-\mathrm{H}-\mathrm{R}$ units of secretin $(S)$ and $2.0 \mathrm{C}-\mathrm{H}-\mathrm{R}$ units of pancreozymin $(P)$, showing mean $\pm 2 S E$ of mean.

- alkaline phosphatase.
was sucrase)
For the postsecretin alkaline phosphatase rise $p<0.004$
For the postpancreozymin rise $p<0.01$




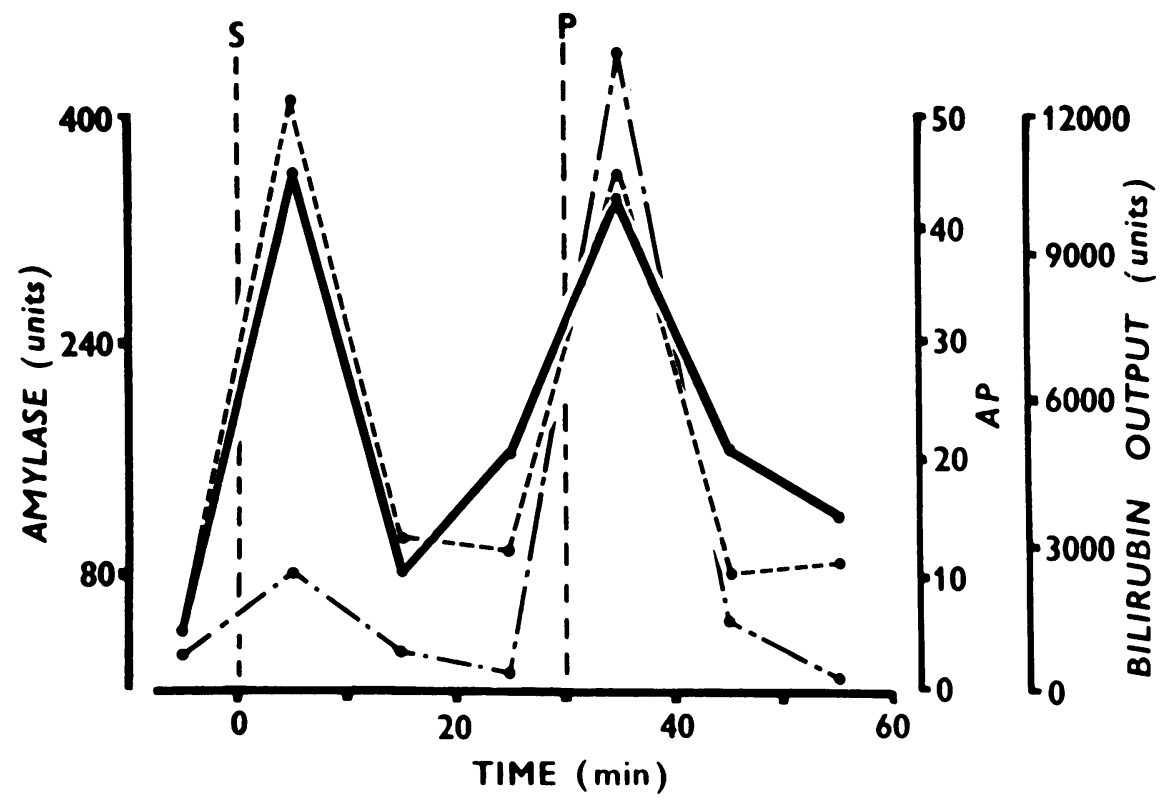

Fig 2 Mean outputs of alkaline phosphatase, amylase, and bilirubin in 16 normals following secretin and pancreozymin.

output of these disaccharidases following secretin or pancreozymin.

Human pancreatic juice obtained in 15 patients from drainage of the pancreatic duct contained very little alkaline phosphatase, the mean value being $0.9 \mathrm{KA}$ units \% (table I). The mean concentration of alkaline phosphatase in pancreatic juice obtained from one patient on 23 occasions was $0.04 \mathrm{KA}$ units \%(range 0-0.4). Pancreatic juice obtained from the cannulated pancreatic duct of another patient with chronic pancreatitis contained no alkaline phosphatase following intravenous secretin and pancreozymin (table II).

\section{PATIENTS WITH COMPLETE BILIARY OBSTRUCTION}

Secretin and pancreozymin were given to 14 patients

\begin{tabular}{lllll}
\hline & $\begin{array}{l}\text { Amylase } \\
(\text { units } / m l)\end{array}$ & $\begin{array}{l}\text { Icteric } \\
\text { Index } \\
(\text { units } / m l)\end{array}$ & $\begin{array}{l}\text { Maltase } \\
(\text { IU/ml) } \\
(4 \text { samples })\end{array}$ & $\begin{array}{l}\text { Alkaline } \\
\text { Phosphatase } \\
(\text { KA units }) \\
100 \mathrm{ml})\end{array}$ \\
\hline Mean & $7 \cdot 2$ & 0 & 0.013 & 0.9 \\
1 SD & 4.4 & 0 & 0.004 & 1.8 \\
Range & $2 \cdot 4-14.7$ & 0 & $0.008-0.018$ & $0-6.0$ \\
\hline
\end{tabular}

Table I Human pancreatic juice (15 patients)

\begin{tabular}{|c|c|c|c|}
\hline & $\begin{array}{l}\text { Amylase } \\
\text { (units } / m l \text { ) }\end{array}$ & $\begin{array}{l}\text { Lipase } \\
(I U / m l)\end{array}$ & $\begin{array}{l}\text { Alkaline } \\
\text { Phosphatase } \\
\text { (KA units/ } \\
100 \mathrm{ml})\end{array}$ \\
\hline Control & $2 \cdot 8$ & 193 & 0 \\
\hline After intravenous secretin & $2 \cdot 3$ & 117 & 0 \\
\hline $\begin{array}{l}\text { After intravenous } \\
\text { pancreozymin }\end{array}$ & $3 \cdot 2$ & 150 & 0 \\
\hline
\end{tabular}

Table II Human pancreatic juice following intravenous secretin and CCK-pancreozymin (1.7 C-H-R units/kg in each case) in a patient with chronic pancreatitis

\begin{tabular}{lccc}
\hline $\begin{array}{l}\text { Outputs of Alkaline } \\
\text { (KA units) }\end{array}$ & Phosphatase & Mean \pm of Mean \\
\hline Group & $\begin{array}{l}\text { Postsecretin } \\
\text { Period }\end{array}$ & $\begin{array}{l}\text { Postpancreozy- Total Output } \\
\text { min Period }\end{array}$ \\
\hline Normals (16) & 75.5 & 79.6 & 155.1 \\
& \pm 17.9 & \pm 36.4 & \pm 45.2 \\
Complete biliary & 48.1 & 37.3 & 85.4 \\
obstruction (14) & \pm 13.1 & \pm 10.9 & \pm 18.2 \\
\hline
\end{tabular}

Table III Mean 30-minute outputs of alkaline phosphatase for the 30-minute periods following secretin and pancreozymin 1

${ }^{1}$ The right-hand column shows the mean total output during the course of the test. The total output in patients with complete biliary obstruction was less than in the normal group but this difference is not statistically significant $(P>0 \cdot 1)$. 


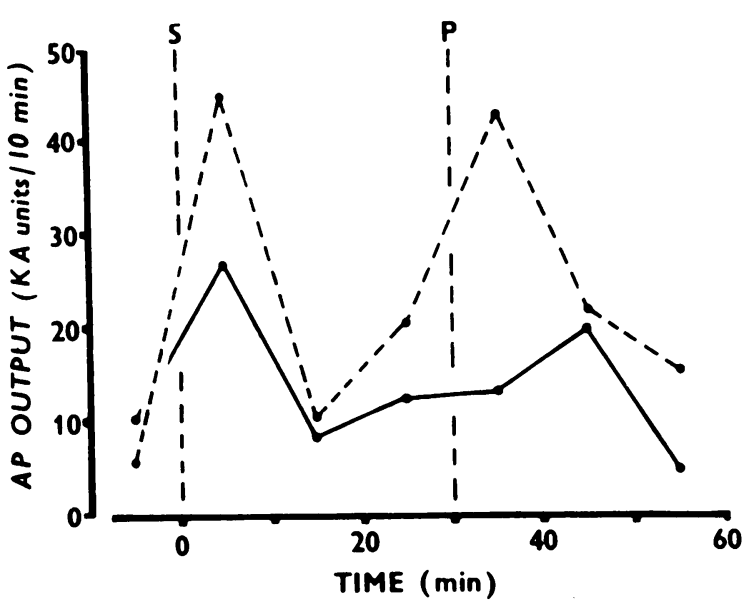

Fig 3 Mean output of alkaline phosphatase following secretin and pancreozymin in 14 patients with complete biliary obstruction.

complete biliary obstruction

- - - - - - - mean normal

For postsecretin $v$. control in complete biliary obstruction $p<0.0001$

For the postpancreozymin rise $p>0.05$

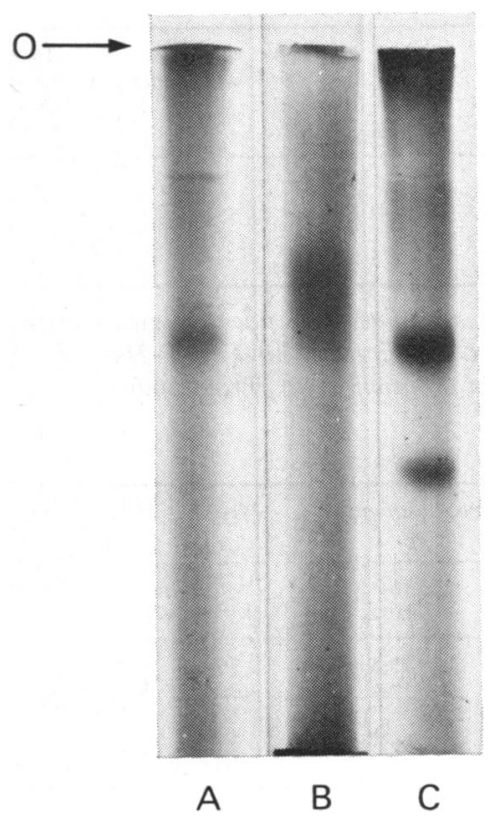

Fig 4 Acrylamide gel disc electrophoresis. Left to right.
A small-intestinal extract
B pancreatic extract
C bile

(O marks the origin)

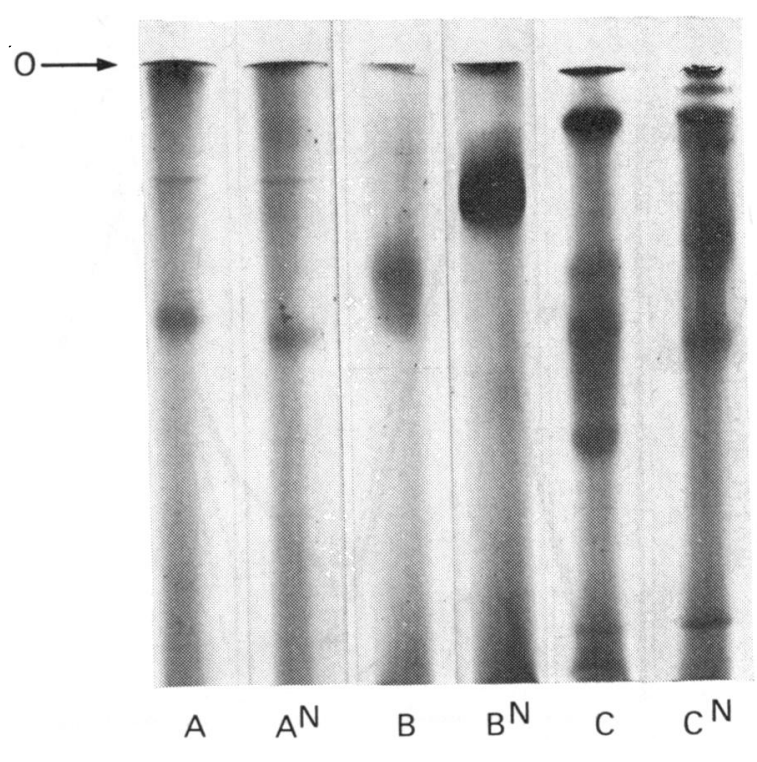

Fig 5 The effect of neuraminidase on electrophoretic mobility. Left to right.

A small-intestinal extract

B pancreatic extract

$\mathrm{C}$ bile

(the right-hand gel of each pair, superscript $N$, has

been preincubated with neuraminidase)

with complete biliary obstruction; in all cases the duodenal juices contained no bilirubin throughout the period of the test. The mean 30-minute outputs of alkaline phosphatase are shown in table III. In these patients with complete biliary obstruction there was a highly significant rise in output following secretin ( $P<0.001$ ), though the mean rise following pancreozymin did not reach statistical signilicance (fig 3).

On acrylamide gel disc electrophoresis (fig 4), pancreatic alkaline phosphatase gave a diffuse band running in a similar position to intestinal alkaline phosphatase which was, however, much more compact, whilst bile alkaline phosphatase had in addition to the slow-running band a faster band running in the same position as that of the main band in serum. Another important difference was brought out by incubation with neuraminidase before electrophoresis; the electrophoretic mobility of smallintestinal alkaline phosphatase was unaltered by prior incubation with neuraminidase (fig 5), whilst pancreatic alkaline phosphatase was slowed by neuraminidase, as was biliary alkaline phosphatase. The enzymes were further characterized by their 


\begin{tabular}{|c|c|c|c|}
\hline & \multicolumn{3}{|c|}{ Percentage Alkaline Phosphatase after } \\
\hline & $\begin{array}{l}\text { L-Phenylala- } \\
\text { nine Inhibition } \\
(0.005 M)\end{array}$ & $\begin{array}{l}\text { Heat at } 56^{\circ} \\
\text { for } 15 \text { Minutes }\end{array}$ & $\begin{array}{l}\text { 30-min Urea } \\
\text { Preincubation } \\
\text { (1M) }\end{array}$ \\
\hline \multirow[t]{2}{*}{ Small-intestinal (5) } & $21 \cdot 1$ & $78 \cdot 3$ & $44 \cdot 2$ \\
\hline & $\pm \mathbf{6 \cdot 0}$ & $\pm 13 \cdot 1$ & $\pm 7 \cdot 7$ \\
\hline \multirow[t]{2}{*}{ Bile (16) } & $89 \cdot 3$ & $35 \cdot 8$ & $42 \cdot 6$ \\
\hline & $\pm 17 \cdot 0$ & $\pm 19 \cdot 2$ & $\pm 18 \cdot 1$ \\
\hline \multirow[t]{2}{*}{ Pancreatic (6) } & $88 \cdot 5$ & $10 \cdot 3$ & $11 \cdot 4$ \\
\hline & $\pm 10 \cdot 8$ & $\pm \mathbf{9 \cdot 8}$ & $\pm 12 \cdot 0$ \\
\hline
\end{tabular}

Table IV The biochemical characteristics of the bile, pancreatic, and small-intestinal isoenzymes of alkaline phosphatase + $1 S D$

inhibition with $0.005 \mathrm{M}$ L-phenylalanine and their stability to heat and urea (table IV). Whilst only $21 \%$ of the intestinal alkaline phosphatase activity remained after inhibition with $0.005 \mathrm{M}$ L-phenylalanine, both bile and pancreatic alkaline phosphatase were virtually unaffected by this inhibitor.

\section{PATIENTS WITH COMPLETE PANCREATIC}

\section{AND BILIARY OBSTRUCTION}

In seven patients with complete obstruction to both the pancreatic and the common bile ducts (table V), there was a significant rise in output of alkaline phosphatase following secretin $(\mathrm{P}<0.02)$ and pancreozymin $(P \bumpeq 0.02$, Wilcoxon test). In six out of the seven cases the postpancreozymin rise was small, but in one patient (no. 4) a large rise in output of alkaline phosphatase following pancreozymin was obtained (fig 6). The electrophoretic mobility of this postsecretin and postpancreozymin juice alkaline phosphatase was identical to that of the small-intestinal extract (fig 7). That this was intestinal alkaline phosphatase was further confirmed by electrophoresis after incubation with neuraminidase. Just as neuraminidase failed to alter the electrophoretic mobility of small-intestinal extract alkaline phosphatase, it failed to alter the mobilities of the alkaline phosphatase of the postsecretin or the postpancreozymin juices (fig 8).

\begin{tabular}{|c|c|c|c|c|}
\hline \multirow[t]{2}{*}{ Case No. } & \multicolumn{4}{|c|}{ Alkaline Phosphatase (KA units/10 min) } \\
\hline & Control 1 & $\begin{array}{l}\text { After } \\
\text { Secretin }\end{array}$ & Control 2 & $\begin{array}{l}\text { After } \\
\text { Pancreozymin }\end{array}$ \\
\hline 1 & $3 \cdot 8$ & $5 \cdot 7$ & 0 & 3.8 \\
\hline 2 & $2 \cdot 1$ & $5 \cdot 1$ & 1.8 & $2 \cdot 5$ \\
\hline 3 & 0 & $6 \cdot 25$ & 0.4 & 1.6 \\
\hline 4 & 1.05 & $30 \cdot 0$ & $30 \cdot 0$ & $56 \cdot 0$ \\
\hline 5 & 1.25 & $6 \cdot 6$ & 1.0 & 3.4 \\
\hline 6 & $6 \cdot 36$ & $28 \cdot 2$ & $7 \cdot 4$ & $9 \cdot 3$ \\
\hline 7 & $6 \cdot 16$ & $8 \cdot 73$ & $1 \cdot 7$ & $5 \cdot 3$ \\
\hline Mean & $2 \cdot 96$ & $12 \cdot 94$ & $6 \cdot 04$ & $11 \cdot 70$ \\
\hline $1 \mathrm{SD}$ & $2 \cdot 54$ & $11 \cdot 11$ & $10 \cdot 85$ & $19 \cdot 69$ \\
\hline
\end{tabular}

Table $\mathrm{V}$ Ten-minute outputs in complete pancreatic and biliary obstruction

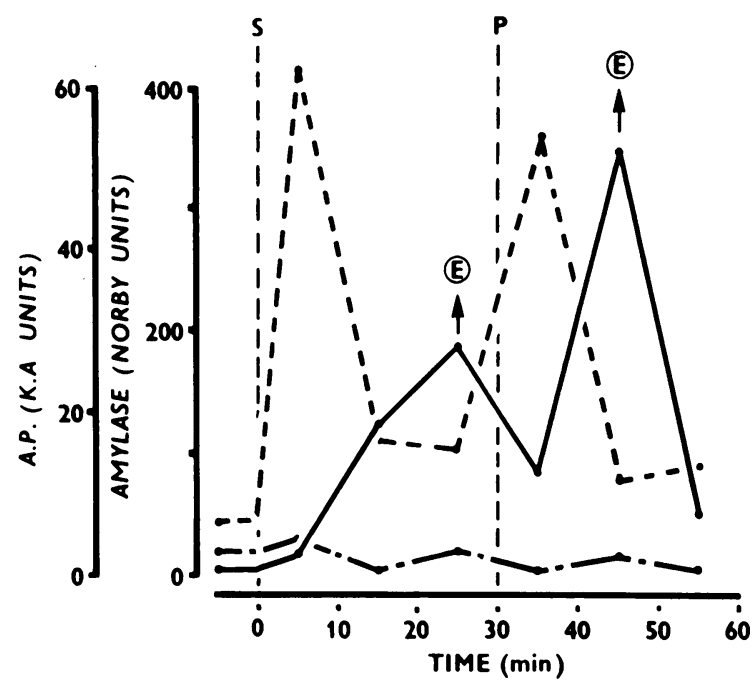

Fig 6 Output of alkaline phosphatase following secretin and pancreozymin in a patient with complete obstruction of the pancreatic and bile ducts.

$$
\begin{aligned}
& -A P \\
& -\cdot-\cdot-\cdot-\text { amylase } \\
& ---\ldots--- \text { mean amylase in normals }
\end{aligned}
$$

Bilirubin was zero throughout.

(E) Denotes samples that were electrophoresed (see fig 7).

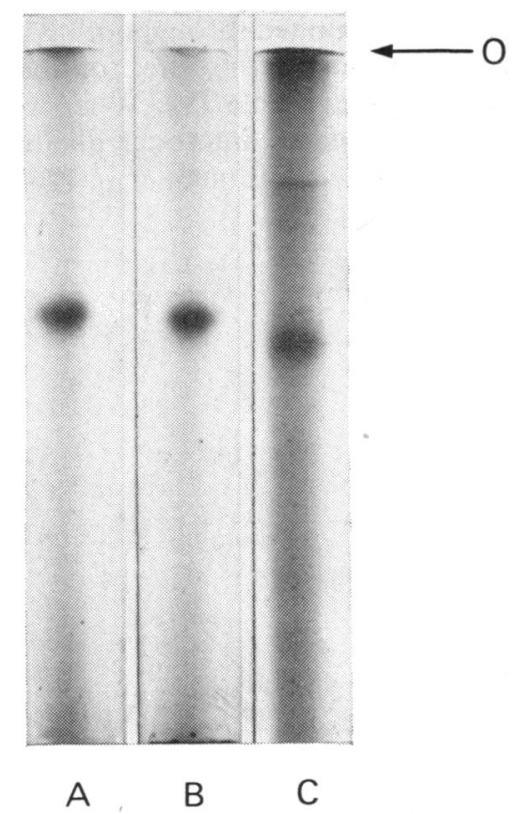

Fig 7 Electrophoresis of duodenal juice from a patient with pancreatic and bile duct obstruction.

A small-intestinal extract

B postsecretin juice

C postpancreozymin juice 


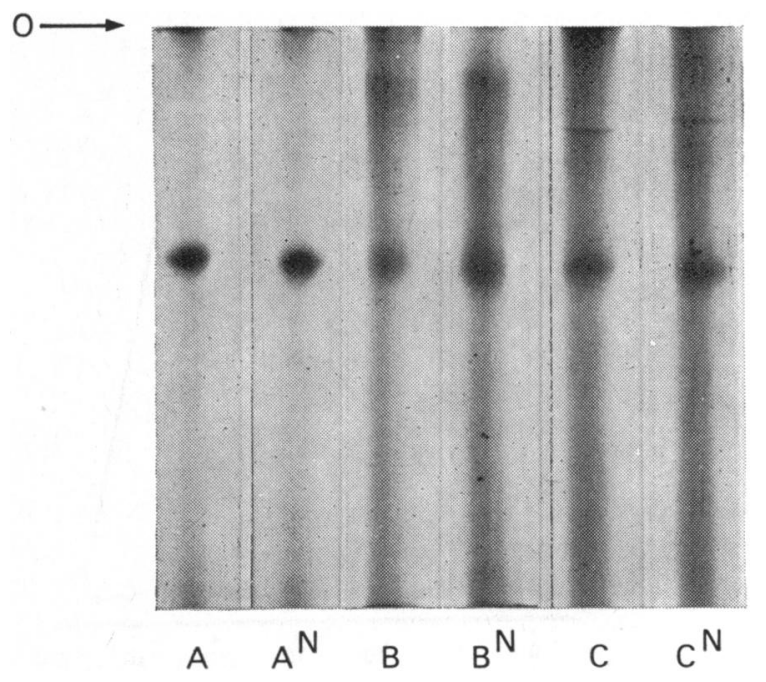

Fig 8 The effect of neuraminidase on the electrophoretic mobility of duodenal juice.

A small-intestinal extract

B postsecretin juice

C postpancreozymin juice

(The right-hand gel of each pair, superscript $N$, has been preincubated with neuraminidase.)

Furthermore, the postsecretin and postpancreozymin alkaline phosphatase was, like that of the intestine, strongly inhibited throughout by L-phenylalanine, which has virtually no effect on the bile and pancreatic isoenzymes (table IV). When values for the 10-minute outputs of intestinal alkaline phosphatase were calculated (Fishman et al, 1963) on the

\begin{tabular}{|c|c|c|c|c|}
\hline Time (min) & $\begin{array}{l}\text { Alkaline } \\
\text { Phosphatase } \\
\text { Concentra- } \\
\text { tion }(K A \text { units } \\
\text { per } 100 \mathrm{ml})\end{array}$ & $\begin{array}{l}\text { Ten-minute } \\
\text { Output } \\
\text { of Alkaline } \\
\text { s Phosphatase } \\
\text { (KA units) }\end{array}$ & $\begin{array}{l}\text { Inhibition } \\
\text { with } 0.005 M \\
\text { L-phenyl- } \\
\text { alanine } \\
(\%)\end{array}$ & $\begin{array}{l}\text { Ten-minute } \\
\text { Output of } \\
\text { Intestinal } \\
\text { Alkaline } \\
\text { Phosphatuse } \\
\text { (KA units) }\end{array}$ \\
\hline C & 35.0 & $1 \cdot 1$ & 76.9 & 1.0 \\
\hline $\begin{array}{l}\text { Secretin } \\
10 \\
20 \\
30\end{array}$ & $\begin{array}{r}36.8 \\
475.0 \\
250.0\end{array}$ & $\begin{array}{r}3.0 \\
19.0 \\
30.0\end{array}$ & $\begin{array}{l}67 \cdot 9 \\
77 \cdot 5 \\
74 \cdot 8\end{array}$ & $\begin{array}{r}2.7 \\
18.6 \\
28.4\end{array}$ \\
\hline $\begin{array}{l}\text { Pancreozym } \\
40 \\
50 \\
60\end{array}$ & $\begin{array}{r}\text { in } \\
433 \cdot 0 \\
700 \cdot 0 \\
167 \cdot 0\end{array}$ & $\begin{array}{r}13.0 \\
56.0 \\
8.4\end{array}$ & $\begin{array}{l}78.6 \\
75.0 \\
74.4\end{array}$ & $\begin{array}{r}12.9 \\
52.3 \\
7.9\end{array}$ \\
\hline
\end{tabular}

Table VI Rise in concentration and output of intestinal alkaline phosphatase following secretin and pancreozymin in complete pancreatic and common bile duct obstruction

basis of our experimental finding of $78.9 \%$ inhibition of small-intestinal alkaline phosphatase by Lphenylalanine, it was clear that there was a substantial rise in output of intestinal alkaline phosphatase in duodenal juice following both secretin and pancreozymin (table VI). Furthermore, this rise in concentration and output of intestinal alkaline phosphatase was reproduced when a second injection of secretin was administered (fig 9).

\section{Discussion}

Although the output of alkaline phosphatase in biliary obstruction is less than in normal subjects, this difference is not statistically significant, which suggests that a major proportion of the enzyme in duodenal juice must arise from sources other than bile.

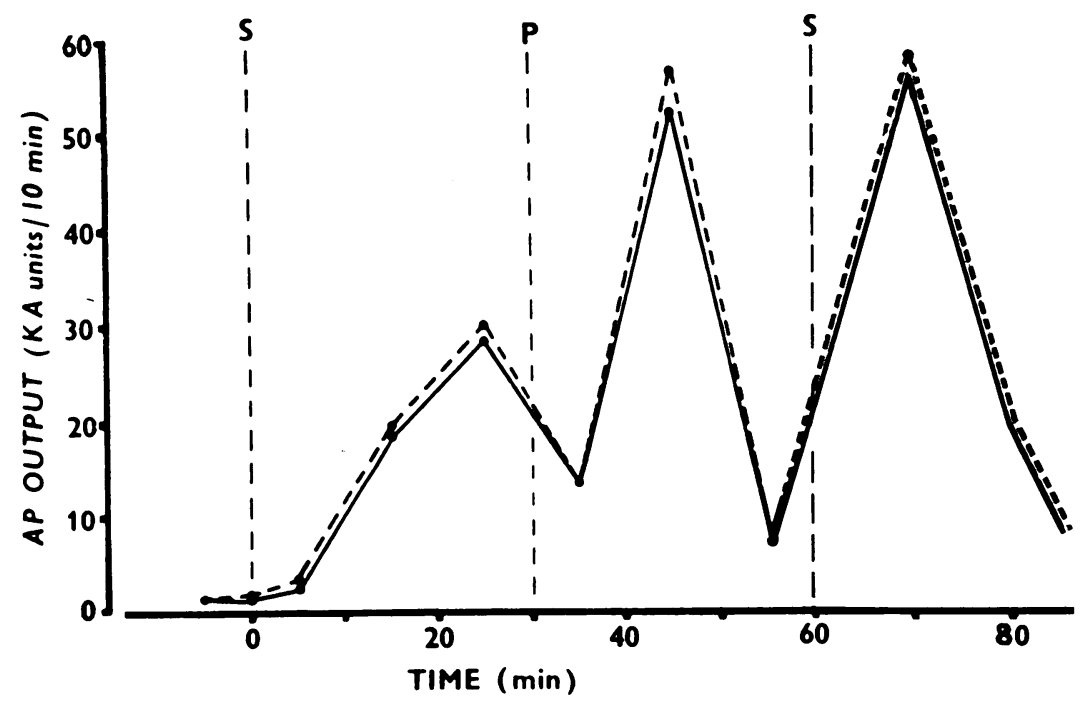

Fig 9 Output of intestinal alkaline phosphatase following secretin, pancreozymin, and a second injection of secretin in a patient with complete pancreatic and common bile duct obstruction. intestinal $A P$ -------- total $\boldsymbol{A P}$ 
Alkaline phosphatase has been demonstrated histochemically in the acini as well as in the islet cells of the human pancreas (Warnes and Bulmer, 1970). However, in contrast to the gland itself, human pancreatic juice contains negligible amounts of the enzyme, and the fact that a rise in output of alkaline phosphatase persists after both secretin and pancreozymin in patients with complete biliary obstruction therefore suggests that both hormones cause it to be liberated from the small-intestinal mucosa. This suggestion is considerably strengthened by the finding that the rises in output persist in patients with complete pancreatic and biliary obstruction, and that the isoenzyme studies confirm that the raised output is of intestinal origin. It is therefore clear that both secretin and pancreozymin have a direct action on small-intestinal alkaline phosphatase which is not dependent on the presence of bile salts or pancreatic enzymes. Nevertheless, the rise in output following pancreozymin in the obstructed group was frequently small and delayed, and it is therefore possible that the presence of bile or pancreatic juice is required for pancreozymin to exert its maximum effect on smallintestinal alkaline phosphatase.

The mechanism by which both hormones act on small-intestinal alkaline phosphatase has to be considered in the context of existing knowledge of the mechanisms by which hormones may produce changes in function of the small intestine. Some hormones, such as growth hormone (Leblond and Carriere, 1955), are thought to act by a mitogenic action on the intestinal crypts, and others such as glucagon increase blood flow to the small intestine (Varró and Csernay, 1966), whilst parathormone increases gut motility (Segerström and Ohrn, 1972). All of these factors may, in turn, affect cell loss and extrusion at the tips of the villi (Levin, 1969). Secretin is known to increase splanchnic blood flow in the experimental animal but it decreases duodenal motility (Hubel, 1972). Cholecystokinin-pancreozymin, on the other hand, initiates duodenal peristalsis in experimental animals (Sandblom, Voegtlin, and Ivy, 1935), and has a similar effect on smallbowel motility in man (Parker and Beneventano, 1970). Since both hormones increase the volume of bile and pancreatic juice perfusing the small intestine, and since Boots secretin of the type used in this study has, in the dog, been shown to stimulate the secretion of fluid from Brunner's glands (Cooke and Grossman, 1966), a direct 'wash-off' effect is possible. Increasing the rate of perfusion of the small intestine in rats increases the rate of desquamation of epithelial cells into the intestinal lumen with a corresponding loss of DNA and protein (Da Costa, Croft, and Creamer, 1971). However, this is unlikely to be the whole explanation of the mode of action of the two hormones on smallintestinal alkaline phosphatase, since they both release brush border alkaline phosphatase into duodenal juice in the presence of complete biliary and pancreatic duct obstruction, and since, as is shown in fig 9, a second injection of secretin is effective in releasing intestinal alkaline phosphatase into the gut lumen. Finally, a simple 'wash-off' effect fails to explain our observation that secretin and pancreozymin do not produce an equivalent rise in the output of disaccharidases. It is possible that the action of both hormones on small-intestinal alkaline phosphatase is mediated through cyclic AMP, which is known to be present in the mucosa of the small intestine (Sutherland and Rall, 1960). Alternatively, secretin and CCK-pancreozymin may produce a change in the conformational state of intestinal alkaline phosphatase analogous to the action of adrenal glucocorticoids on alkaline phosphatase which has been shown to be due to the activation of a preexisting enzyme rather than to increased enzyme synthesis (Griffin and Cox, 1966).

Alkaline phosphatase may be concerned in carbohydrate digestion (Verzár and Sailer, 1952) and glucose is capable of stimulating the intestinal mucosa to secrete an L-phenylalanine-sensitive alkaline phosphatase (Linscheer et al, 1967). Hydrolysis of disaccharides takes place within the intact mucosal epithelial cell (Miller and Crane, 1961a) and the intestinal brush border is considered to constitute a digestive surface in which the final stages of carbohydrate digestion occur (Miller and Crane, 1961b). Since disaccharidases and alkaline phosphatase are similarly localized in the brush border region, some workers have suggested that they have a common function in the final stages of carbohydrate digestion on the brush border (Holt and Miller, 1962). However, generalizations based on a knowledge of the mode of action of the disaccharidases are not necessarily applicable to other enzymes found on the brush border, since, as we have shown, alkaline phosphatase is present in high concentrations in succus entericus which contains virtually no disaccharidase.

Recent work suggests that intestinal alkaline phosphatase is concerned in calcium transport (Norman, Mircheff, Adams, and Spielvogel, 1970; Haussler, Nagode, and Rasmussen, 1970), and the enzyme is known to be implicated in fat absorption from the small intestine, particularly of oleic acid (Linscheer, Malagelada, and Fishman, 1971), a process in which secretin- and pancreozymin-mediated release of brush border alkaline phosphatase may be concerned since both hormones are released by the hydrolytic products of fat in the intestinal lumen. 
However, both the mechanisms of action of secretin and CCK-pancreozymin on small-intestinal alkaline phosphatase and the function of the enzyme so released into duodenal juice remain at this stage largely speculative, but the measurement of the levels in duodenal juice during the course of the secretin-pancreozymin test can provide useful additional information in patients with biliary tract and pancreatic pathology, whilst extending the value of the test by providing information about small-intestinal function. A further communication on this subject is in preparation (Warnes and Howat, 1974).

Though studies of the hormonal stimulus to smallintestinal secretion in experimental animals date back to 1904 (Delezenne and Frouin, 1904), we are not aware of any description of hormonal action on the brush border or its enzymes in the human being before this work. ${ }^{1}$ Traditionally it has been considered that filtered cell-free juice contains only two secreted digestive enzymes, namely, enterokinase and amylase (Magee, 1962). Indeed, some authorities felt that it was doubtful whether the 'succus entericus' contained any secreted digestive enzymes at all (Dahlqvist and Borgström, 1961). It is likely that our finding of high concentrations of alkaline phosphatase in human small-intestinal secretions, and of its release into duodenal juice by hormonal means, will necessitate a review of the role of succus entericus in digestion, particularly since information is now available about the possible role of small-intestinal alkaline phosphatase (Warnes, 1972).

This work was supported by a grant from the Research Grants Committee, United Manchester Hospitals.

We wish to record our great debt to Professor H. T. Howat for his help and encouragement at every stage in this work. We also wish to thank Professor H. Sarles of Marseilles for supplying us with four specimens of lyophilized human pancreatic juice, and Mrs D. A. Willans for performing the disaccharidase estimations. We are grateful to the Department of Medical Illustration, Manchester Royal Infirmary, for the photographs and diagrams, and to Mrs D. Riley for secretarial assistance.

\section{References}

Bahr, M., and Wilkinson, J. H. (1967). Urea as a selective inhibitor of

${ }^{1}$ This work was presented at the symposium on small-intestinal enzymes at the 4th World Congress of Gastroenterology in July 1970 (Warnes, Hine, and Kay, 1970). The action of pancreozymin on smallintestinal alkaline phosphatase has been recently confirmed in the expermental animal (Götze, Adelson, Hadorn, Portmann, and Troesch, 1972). human tissue alkaline phosphatases. Clin. chim. Acta, 17, 367-370.

Burton, P., Evans, D. G., Harper, A. A., Howat, H. T., Oleesky, S., Scott, J. E., and Varley, H. (1960a). A test of pancreatic function in man based on the analysis of duodenal contents after administration of secretin and pancreozymin. Gut, 1 . 111-124.

Burton, P., Harper, A. A., Howat, H. T., Scott, J. E., and Varley, H. (1960b). The use of cholecystokinin to test gall bladder function in man. Gut, 1, 193-204.

Cherry, I. S., and Crandall, L. A., Jr. (1932). The specificity of pancreatic lipase; its appearance in the blood after pancreatic injury. Amer. J. Physiol., 100, 266-273.

Cooke, A. R., and Grossman, M. I.(1966). Studies on the secretion and motility of Brunner's gland pouches. Gastroenterology, 51, 506-514.

Da Costa, L. R., Croft, D. N., Creamer, B. (1971). Protein loss and cell loss from the small-intestinal mucosa. Gut, 12, 179-183.

Dahlqvist, A. (1964). Method of assay of intestinal disaccharidases. Analyt. Biochem., 7, 18-25.

Dahlqvist, A., and Borgström, B. (1961). Digestion and absorption of disaccharides in man. Biochem. J., 81, 411-418.

Delezenne, C., and Frouin, A. (1904). La sécrétion physiologique du suc intestinal. Action de l'acide chlorhydrique sur la sécrétion duodénale. C. R. Soc. Biol. (Paris), 56, 319-322.

Fishman, W. H., Green, S., and Inglis, N. I. (1963). L-phenylalanine: an organ specific, stereo-specific inhibitor of human intestinal alkaline phosphatase. Nature (Lond.), 198, 685-686.

Gomori, G. (1941). Distribution of phosphatase in normal organs and tissues. J. cell. comp. Physiol., 17, 71-83.

Götze, H., Adelson, J. W., Hadorn, H. B., Portmann, R., and Troesch, V. (1972). Hormone-elicited enzyme release by the small intestinal wall. Gut, 13, 471-476.

Gowenlock, A. H. (1953). The estimation of tryptic activity in duodenal contents. Biochem. J., 53, 274-277.

Greene, C. H., Shattuck, H. F., and Kaplowitz, L. (1934). The phosphatase content $\mathrm{cf}$ the blood serum in jaundice. $J$. clin. Invest., 13, 1079-1087.

Griffin, M. J., and Cox, R. P. (1966). Studies on the mechanism of hormone-induction of alkaline phosphatase in human cell cultures. II. Rate of enzyme synthesis and properties of base level and induced enzymes. Proc. nat. Acad. Sci. (Wash.), 56. 946-953.

Haussler, M. R., Nagode, L. A., and Rasmussen, H. (1970). Induction of intestinal brush border alkaline phosphatase by Vitamin $\mathrm{D}$ and identity with Ca-ATPase. Nature (Lond.), 228, 1199. 1201.

Holt, J. H., and Miller, D. (1962). The localization of phosphomonoesterase and aminopeptidase in brush borders isolated from intestinal epithelial cells. Biochim. biophys. Acta (Amst.), 58, 239-243.

Hubel, K. A. (1972). Secretin: a long progress note. Gastroenterology, 62, 318-341.

Kaplan, M. M., and Rogers, L. (1969). Separation of human serumalkaline-phosphatase isoenzymes by polyacrylamide gel electrophoresis. Lancet, 2, 1029-1031.

Kind, P. R. N., and King, E. J. (1954). Estimation of plasma phosphatase by determination of hydroysed phenol with aminoantipyrine. J. clin. Path., 7, 322-326.

Lagerhöf, H. O. (1942). Pancreatic function and pancreatic disease studied by means of secretin. Acta med. scand., Suppl., 128 , 18-33.

Leblond, C. P., and Carriere, R. (1955). The effect of growth hormone and thyroxine on the mitotic rate of the intestinal mucosa of the rat. Endocrinology, 56, 261-266.

Levin, R. J. (1969). The effects of hormones on the absorptive, metabolic, and digestive functions of the small intestine. $J$. Endocr., 45, 315-348.

Linscheer, W. G., Blum, A. L., Inglis, N. I., and Fishman, W. H. (1967). Intestinal alkaline phosphatase during glucose absorption in man. (Abstr.) Clin. Res., 15, 238.

Linscheer, W. G., Malagelada, J. R., and Fishman, W. H. (1971). Diminished oleic acid absorption in man by L-phenylalanine inhibition of an intestinal phosphohydrolase. Nature [new' Biol.], 231, 116-117.

Linscheer, W. G., Pihl, O., Wehr, H., and Fishman, W. H. (1970). Enzyme release from human duodenal mucosa: effects of chain length of infused fatty acids. (Abstr.) Gastroenteroogy, 58, 970 . 
Magee, D. F. (1962). The secretion of the small intestine. In his Gastrointestinal Physiology. Thomas, Springfield, Illinois.

Miller, D., and Crane, R. K. (1961a). The digestive function of the epithelium of the small intestine. I. An intracellular locus of disaccharide and sugar phosphate ester hydrolysis. Biochim. biophys. Acta (Amst.), 52, 281-293.

Miller, D., and Crane, R. K. (1961b). The digestive function of the epithelium of the small intestine. II. Localisation of disaccharide hydrolysis in the isolated brush border portion of the intestinal epithelial cells. Biochim. biophys. Acta (Amst.), 52, 293-298.

Morton, R. K. (1954). The purification of alkaline phosphatase of animal tissues. Biorhem. J., 57, 595-603.

Newton, M. A. (1967). The clinical application of alkaline phosphatase electrophoresis. Cuart. J. Med., 36, 17-28.

Norman, A. W., Mircheff, A. K., Adams, T. H., and Spielvogel, A. (1970). Studies on the mechanism of action of calciferol. III. Vitamin D-mediated increase of intestinal brush border alkaline phosphatase activity. Biochim. biophys. Acta (Amst.), 215, 348-359.

Nothmann, M. M. (1944). Effect of ligation of pancreatic ducts on the serum phosphatase. Proc. Soc. exp. Biol. (N.Y.), 57, 15-16.

Parker, J. G., and Beneventano, T. C. (1970). Acceleration of small bowel contrast study by cholecystokinin. Gastroenterology, 58, 679-684.

Posen, S., Neale, F. C., and Clubb, J. S. (1965). Heat inactivation in the study of human alkaline phosphatases. Ann. intern. Med., 62, 1234-1243.

Robinson, J. C., and Pierce, J. E. (1964). Differential action of neuraminidase on human serum alkaline phosphatases.Nature (Lond.), 204, 472-473.

Sandblom, P., Voegtlin, W. L., and Ivy, A. C. (1935). The effect of cholecystokinin on the choledocho-duodenal mechanism. Amer. J. Physiol., 113, 175-180.
Segerström, A., and Ohrn, P. G. (1972). Glucocorticoid influence on serum calcium level and gastrointestinal motility in rats with varied parathyroid function. Scand. J. Gastroent., 7, 185-192.

Sutherland, E. W., and Rall, T. W. (1960). The relation of adenosine3',5'-phosphate and phosphorylase to the actions of catecholamines and other hormones. Pharmacol. Rev., 12, 265-299.

Varrö, V., and Csernay, L. (1966). The effect of intra-arterial insulin and glucagon on the glucose metabolism of the small intestine in the dog. Scand. J. Gastroent., 1, 232-237.

Verzar, F., and Sailer, E. (1952). Glukose-Resorption und alkalische Phosphatase des Dünndarmes nach Adrenalektomie bei mit $\mathrm{NaCl}$ behandelten Tieren. Helv. physiol. pharmacol. Acta, 10, 247-258.

Wang, C. C., and Grossman, M. I. (1951). Physiological determination of release of secretin and pancreozymin from intestine of dogs with transplanted pancreas. Amer. J. Physiol., 164, 527-545.

Warnes, T. W. (1972). Alkaline phosphatase. Gut, 13, 926-937.

Warnes, T. W., and Bulmer, D. (1970). Histochemical studies on pancreatic alkaline phosphatase. (Abstr.) J. Anat. (Lond.), 106, 410.

Warnes, T. W., Hine, P., and Kay, G. (1969). Alkaline phosphatase in duodenal juice following secretin and pancreozymin. (Abstr.) Gut, 10, 1049.

Warnes, T. W., Hine, P., and Kay, G. (1970). The action of secretin and pancreozymin on small-intestinal alkaline phosphatase (Abstr.). In 4th World Congress of Gastroenterology, Copenhagen, edited by P. Riis, P. Anthonisen, and H. Baden, p. 131. DIS Congress Service, DK-1159 Copenhagen $\mathrm{K}$.

Warnes, T. W., and Howat, H. T. (1974). The diagnostic value of alkaline phosphatase in duodenal juice in diseases of the biliary tract, pancreas and small intestine. (In preparation).

Warnes, T. W., Timperley, W. R., Hine, P., and Kay, G. (1972). Pancreatic alkaline phosphatase and a tumour variant. Gut, 13, 513-519. 